\title{
Ribavirin Aerosol in the Treatment of SARS-CoV-2: A Case Series
}

\author{
Emanuela Messina · Anna Danise · Giulio Ferrari · Andrea Andolina • \\ Matteo Chiurlo · Marie Razanakolona · Maxime Barakat • \\ Robert J. Israel · Antonella Castagna
}

Received: April 30, 2021 / Accepted: June 28, 2021 / Published online: July 23, 2021

(C) The Author(s) 2021

\section{ABSTRACT}

Ribavirin is an inosine monophosphate dehydrogenase inhibitor with demonstrated activity against coronaviruses, including SARS-CoV-2. Five hospitalized patients with COVID-19 (confirmed by positive tests for SARS-CoV-2) received treatment with ribavirin for inhalation solution (ribavirin aerosol) as part of a compassionate use program. Patients included four men and one woman, with an age range of 29-72 years. Patients were managed according to international and Italian treatment guidelines for COVID-19. In addition, therapy with ribavirin aerosol $100 \mathrm{mg} / \mathrm{mL}$ was administered for $30 \mathrm{~min}$ twice daily for 6 days (i.e., 12 doses)

E. Messina - A. Danise - A. Andolina .

M. Razanakolona - A. Castagna $(\square)$

Infectious Diseases Unit, IRCCS San Raffaele

Scientific Institute, Vita-Salute San Raffaele

University, Milan, Italy

e-mail: castagna.antonella1@hsr.it

G. Ferrari

Cornea and Ocular Surface Unit, San Raffaele

Scientific Institute, Milan, Italy

M. Chiurlo · A. Castagna

Infectious Diseases Unit, Vita-Salute San Raffaele

University, Milan, Italy

M. Barakat

Bausch Health, Laval, QC, Canada

R. J. Israel

Bausch Health, Bridgewater, NJ, USA in all patients. In order to address concerns about a possible increase in viral dispersal with the use of a nebulizer, healthcare providers remained outside the patient room during ribavirin aerosol administration. Pretreatment chest computed tomography (CT) scans showed pseudonodular areas of parenchymal thickening in the upper right lobe with associated ground glass opacities, multiple areas of parenchymal consolidation in both lower lobes with associated ground glass opacities, bilateral parenchymal thickening and multiple associated ground glass areas, or focal ground glass areas in the upper lobes bilaterally, which were almost completely resolved (three patients) or moderately cleared (one patient) on imaging at the end of ribavirin treatment. For a fifth patient, CT scans showed a stable pulmonary picture at the end of ribavirin treatment. No adverse reactions to ribavirin treatment were observed in any of the five patients. All patients recovered fully, and nasopharyngeal swabs obtained after hospital discharge tested negative for SARS-CoV-2. Ribavirin aerosol appears to be efficacious in the treatment of patients with COVID-19. A controlled trial of ribavirin aerosol is ongoing and will provide additional data across a broader patient population.

Keywords: Case series; Compassionate use; COVID-19; Ribavirin aerosol; SARS-CoV-2; Virazole 


\section{Key Summary Points}

\section{Why carry out this study?}

Identification of pharmacologic treatments that cause viral clearance of SARS-CoV-2 is important for addressing the global COVID-19 pandemic.

Ribavirin is an inosine monophosphate dehydrogenase inhibitor with activity against coronaviruses, including SARSCoV-2.

It was not known if ribavirin aerosol would be effective in treating hospitalized adults who tested positive for SARS-CoV-2 and were experiencing respiratory distress.

An open-label, compassionate use study was initiated using an experimental dosing regimen of aerosolized ribavirin to deliver medication in a shorter treatment period.

This is the first report of efficacy and safety outcomes in patients treated with ribavirin aerosol for SARS-CoV-2 infection.

\section{What was learned from the study?}

This case series of five hospitalized patients with COVID-19 illustrates the potential benefit of administration of ribavirin aerosol in SARS-CoV-2 viral clearance; further research is ongoing.

\section{INTRODUCTION}

The virus responsible for the coronavirus disease 2019 (COVID-19) pandemic, severe acute respiratory syndrome coronavirus (SARS-CoV)2 , is a betacoronavirus similar to SARS-CoV and the Middle East respiratory syndrome coronavirus (MERS-CoV) [1]. SARS-CoV-2 is known, in some instances, to induce an excessive proinflammatory host response, including aberrant induction of inflammatory cytokines, which is associated with severe lung pathology and can result in patient mortality $[2,3]$. As in patients with SARS-CoV or MERS-CoV, some patients with SARS-CoV-2 infection develop acute respiratory distress syndrome, and pulmonary ground glass opacities are commonly observed on imaging [2, 4]. A 2020 report illustrated similarities between the pathological features observed in a patient with confirmed SARSCoV-2 and those typically seen in SARS-CoV and MERS-CoV infections [5].

Ribavirin is an inhibitor of inosine monophosphate dehydrogenase, a key enzyme in the de novo synthesis of guanine nucleotides, and has demonstrated in vitro activity against a number of emerging viruses [6, 7]. Ribavirin inhibits RNA synthesis by disrupting the activity of viral RNA-dependent RNA polymerases (RdRp), crucial enzymes in the life cycle of coronaviruses, and also inhibits mRNA capping [6-8]. Ribavirin has been used against RdRp of the hepatitis $C$ virus [8], and orally administered ribavirin (in combination with other medications) is approved by the US Food and Drug Administration (FDA) and European Medicines Agency for the treatment of chronic hepatitis C infection $[9,10]$.

Ribavirin for inhalation solution (ribavirin aerosol) is approved by the FDA and Health Canada for the treatment of infants and young children with severe lower respiratory tract infections due to respiratory syncytial virus $[11,12]$ and has been made available in Italy for patients with COVID-19 as part of a compassionate use program. Aerosol administration of ribavirin has been shown to be effective against multiple variants of influenza [13-15]. In order to evaluate the activity of ribavirin and other anti-polymerase drugs against SARS-CoV-2, a 2020 study used homology modeling to build the Wuhan SARS-CoV-2 RdRp and then assessed the binding properties of different antiviral compounds using molecular docking [8]. Authors concluded that ribavirin demonstrated tight binding to the SARS-CoV-2 RdRp and could potentially interfere with protein synthesis, leading to viral eradication [8]. Currently, many countries are using newly developed vaccines to prevent SARS-CoV-2 infection and/or decrease the severity of the 
disease. At the same time, public health authorities are facing important challenges with the current and emerging variants of SARS-CoV2 that could lead to limited efficacy of the available vaccines. For this reason, additional antiviral therapies are needed for patients who will develop more severe infection with SARSCoV-2.

An open-label, compassionate use study was initiated to evaluate the safety and efficacy of ribavirin aerosol $(10 \mathrm{~mL}$ of $100 \mathrm{mg} / \mathrm{mL}$ in nebulizer reservoir administered for $30 \mathrm{~min}$ twice daily [bid] for at most 6 days) in the treatment of hospitalized adults who tested positive for SARS-CoV-2 and were experiencing respiratory distress. Here, data are presented for the first five patients treated for SARS-CoV-2 infection in this compassionate use study.

\section{CASE PRESENTATIONS}

Ethics committee approval of the compassionate use program (IRCCS Lazzaro Spallanzani, Rome, Italy; and San Raffaele Scientific Institute, Milan, Italy) was obtained before treatment was initiated. The study was conducted in accordance with the Helsinki Declaration of 1964 and its later amendments. All patients provided written informed consent for participation in the compassionate use program and for their information and images to be included in this article.

Patients were managed according to international and Italian treatment guidelines for COVID-19. In addition, ribavirin was administered using the PARI BOY ${ }^{\circledR}$ SX inhalation system (PARI GmbH, Starnberg, Germany); the nebulizer was driven by wall air at a standard flow rate. Ribavirin was provided in 6-g vials that were diluted with $60 \mathrm{~mL}$ of distilled water. For each ribavirin treatment, $10 \mathrm{~mL}$ of solution was placed in the nebulizer reservoir. Nebulized ribavirin $(100 \mathrm{mg} / \mathrm{mL}$ for $30 \mathrm{~min}$ bid) was administered for 6 days (i.e., 12 doses total). Healthcare providers remained outside the patient room during ribavirin aerosol administration. Patients were remotely monitored through a window during drug administration, and vital signs were remotely measured every $10 \mathrm{~min}$.

Four men and one woman were treated, with an age range of 29 to 72 years (Table 1). Prior to patient enrollment in the compassionate use program, the diagnosis of COVID-19 was confirmed by positive tests for SARS-CoV-2 (Table 2) and laboratory testing ruled out other bacterial, viral, and fungal etiologies including Legionella, pneumococcus, Chlamydia pneumoniae, Mycoplasma pneumoniae, tuberculosis, cytomegalovirus, human immunodeficiency virus, and aspergillosis.

\section{Patient 1}

The patient was admitted to the hospital on July 8, 2020 (Table 2). Analysis of bronchial washing fluids confirmed the presence of SARSCoV-2 (Table 2), and a chest computed tomography (CT) scan without contrast showed pseudonodular areas of parenchymal thickening in the right upper lobe with associated ground glass areas (involving 15-20\% of the lung parenchyma) and some reactive mediastinal lymph nodes (Fig. 1). The patient was enrolled in the compassionate use study and treated with nebulized ribavirin from July 13 through July 19 . On the third day of ribavirin therapy, a repeat nasopharyngeal swab, a conjunctival sample, and a SARS-CoV-2 antibody test were performed, all of which were negative.

One day after completion of the ribavirin aerosol treatment regimen, a chest CT scan showed resolution of pseudonodular areas previously described, with only minimal residual subpleural areas of parenchymal thickening (less than 5\% of the lung parenchyma; Fig. 1). On the same day, a nasopharyngeal swab tested negative for SARS-CoV-2. The patient was discharged on July 22 (approximately 3 days after completing ribavirin treatment) and returned to quarantine. At the end of quarantine, two sequential nasopharyngeal swabs for SARS-CoV2 yielded negative results. 
Table 1 Patient demographics, clinical characteristics, and test results at the start of ribavirin aerosol therapy

\begin{tabular}{|c|c|c|c|c|c|}
\hline & Patient 1 & Patient 2 & Patient 3 & Patient 4 & Patient 5 \\
\hline Age, years & 33 & 29 & 35 & 61 & 72 \\
\hline Sex & Male & Male & Male & Male & Female \\
\hline $\begin{array}{l}\text { Presenting } \\
\text { symptoms }\end{array}$ & Fever, chills & $\begin{array}{l}\text { Fever, sore } \\
\text { throat, dry } \\
\text { cough, } \\
\text { dysgeusia }\end{array}$ & $\begin{array}{l}\text { Fever, cough, } \\
\text { ageusia, } \\
\text { anosmia }\end{array}$ & $\begin{array}{l}\text { Fever, chills } \\
\text { (close } \\
\text { contact of } \\
\text { COVID-19 } \\
\text { case) }\end{array}$ & Fever, cough, wheezing \\
\hline Medical history & $\begin{array}{l}\text { Helicobacter } \\
\text { pylori gastritis } \\
2 \text { months prior }\end{array}$ & Active smoker & $\begin{array}{l}\text { Pneumonia } \\
\text { in } \\
\text { childhood }\end{array}$ & Unremarkable & $\begin{array}{l}\text { Obesity, hysterectomy, } \\
\text { meningioma (resected), PKD, } \\
\text { kidney transplant, MDR } \\
\text { Klebsiella pneumoniae with } \\
\text { fever }\end{array}$ \\
\hline $\begin{array}{l}\text { Blood pressure, } \\
\text { mmHg }\end{array}$ & $128 / 81$ & $129 / 86$ & $120 / 75$ & $94 / 62$ & $115 / 55$ \\
\hline Cardiac activity & Normal & Normal & Normal & Normal & Tachycardia \\
\hline Pulmonary & $\begin{array}{l}\text { No } \\
\text { bronchospasm } \\
\text { or rales }\end{array}$ & $\begin{array}{l}\text { Crackles in the } \\
\text { middle right } \\
\text { field }\end{array}$ & $\begin{array}{l}\text { Bilateral } \\
\text { crackles in } \\
\text { middle } \\
\text { and basal } \\
\text { fields }\end{array}$ & $\begin{array}{l}\text { Bilateral basal } \\
\text { crackles } \\
\text { (more } \\
\text { pronounced } \\
\text { in left lung) }\end{array}$ & $\begin{array}{l}\text { Tachypnea; vesicular breath } \\
\text { sounds reduced; bilateral } \\
\text { basal crackles (more } \\
\text { pronounced in right lung) }\end{array}$ \\
\hline \multicolumn{6}{|l|}{ Blood gas analysis ${ }^{a}$} \\
\hline $\mathrm{pH}$ & 7.45 & 7.45 & 7.54 & 7.43 & 7.49 \\
\hline $\mathrm{pCO}_{2}, \mathrm{mmHg}$ & 32 & 27 & 31.9 & 38.4 & 26.2 \\
\hline $\mathrm{pO}_{2}, \mathrm{mmHg}$ & 90 & 128 & 77 & 79.6 & 58 \\
\hline $\mathrm{SpO}_{2}, \%$ & 97 & 98 & 96 & 96 & 93 \\
\hline \multicolumn{6}{|l|}{ Laboratory tests ${ }^{\mathrm{b}}$} \\
\hline $\begin{array}{l}\text { WBC count per } \\
\mu \mathrm{L}\end{array}$ & 5000 & 9100 & 7300 & 4000 & 3200 \\
\hline $\begin{array}{l}\text { Lymphocyte } \\
\text { count per } \mu \mathrm{L}\end{array}$ & 1400 & 940 & 1700 & 1800 & 608 \\
\hline $\begin{array}{l}\text { Neutrophil } \\
\text { count per } \mu \mathrm{L}\end{array}$ & 2400 & 7600 & 4600 & 1800 & 2200 \\
\hline $\begin{array}{l}\text { Fibrinogen, mg/ } \\
\mathrm{dL}\end{array}$ & 502 & 599 & 739 & 434 & 509 \\
\hline $\begin{array}{l}\text { C-reactive } \\
\text { protein, } \mathrm{mg} / \mathrm{L}\end{array}$ & 9 & 75 & 90 & 7.8 & 45 \\
\hline
\end{tabular}


Table 1 continued

\begin{tabular}{llllll}
\hline & Patient 1 & Patient 2 & Patient 3 & Patient 4 & Patient 5 \\
\hline $\begin{array}{l}\text { Lactic } \\
\text { dehydrogenase, }\end{array}$ & 390 & 560 & 420 & 275 & 295 \\
U/L & & & & \\
IL-6, pg/mL & 0.6 & 13.8 & 31.8 & 18.2 & 17.3 \\
Ferritin, ng/mL & 301 & 617 & 779 & 420 & NR \\
Chest X-ray & $\begin{array}{l}\text { Negative for } \\
\text { pneumonia }\end{array}$ & $\begin{array}{c}\text { Minimal } \\
\text { accentuation } \\
\text { of interstitial }\end{array}$ & $\begin{array}{c}\text { Slight } \\
\text { interstitial } \\
\text { texture }\end{array}$ & NR & Unclear areas of pulmonary \\
& & & & thickening \\
& & & & \\
\hline
\end{tabular}

$I L$ interleukin, $M D R$ multidrug resistant, $N R$ not reported, $P K D$ polycystic kidney disease

${ }^{a}$ With the patient on room air

b Reference ranges for laboratory tests: WBC count, 4800-10,800 per $\mu \mathrm{L}$; lymphocyte count, $1000-4800$ per $\mu \mathrm{L}$; neutrophil count, $1800-7700$ per $\mu \mathrm{L}$; fibrinogen, $150-400 \mathrm{mg} / \mathrm{dL}$; C-reactive protein, $<6 \mathrm{mg} / \mathrm{L}$; lactic dehydrogenase, 125-200 U/L; IL-6, 0-7 pg/mL; ferritin, 30-400 ng/mL

\section{Patient 2}

A chest CT scan without contrast showed multiple areas of parenchymal consolidation affecting the lower lobes of both lungs with associated ground glass areas, involving 20-25\% of the lung parenchyma (Fig. 2). The patient was admitted to the hospital on July 30, 2020 (Table 2). Serologic testing for SARS-CoV-2 antibodies performed on July 31 was negative. The patient was enrolled in the compassionate use program and treated with nebulized ribavirin from July 31 through August 6. On the third day of ribavirin aerosol therapy, a repeat nasopharyngeal swab tested positive for SARSCoV-2, while a conjunctival sample was negative.

A chest CT scan performed on the last day of ribavirin aerosol treatment showed almost complete resolution of the previously described parenchymal consolidation and ground glass areas (parenchymal involvement of less than $5 \%$; Fig. 2). On the same day, a nasopharyngeal swab tested negative for SARS-CoV-2. Serologic testing performed at the end of ribavirin aerosol therapy was positive for SARS-CoV-2 antibodies. The patient was discharged from the hospital on August 7 and returned to quarantine. At the end of quarantine, two sequential nasopharyngeal swabs for SARS-CoV-2 yielded negative results.

\section{Patient 3}

The patient was admitted to the hospital on October 13, 2020 (Table 2). A chest CT scan without contrast was performed on October 15 and showed bilateral parenchymal thickening and multiple associated ground glass areas with crazy paving (involving approximately $25 \%$ of the lung parenchyma) and some reactive mediastinal lymph nodes (Fig. 3). The patient was enrolled in the compassionate use study and treated with nebulized ribavirin from October 16 through October 22. After the first 2 days of ribavirin therapy, the fever resolved and the cough subsided. At the end of ribavirin therapy, a nasopharyngeal swab test for SARS$\mathrm{CoV}-2$ was negative.

On October 22 (the day of completion of ribavirin aerosol treatment regimen), a chest CT 
Table 2 Diagnostic testing and treatments

\begin{tabular}{|c|c|c|}
\hline Case & Diagnosis & Treatments in addition to ribavirin aerosol ${ }^{a}$ \\
\hline Patient 1 & $\begin{array}{l}\text { Before hospital admission: nasopharyngeal swab } \\
\text { positive for SARS-CoV-2 } \\
\text { After hospital admission: second nasopharyngeal swab } \\
\text { and test for SARS-CoV-2 antibodies both negative } \\
\text { Bronchoscopy and bronchial washing (with antibiotic } \\
\text { solution) performed to aid in diagnosis } \\
\text { Analysis of bronchial washing fluids (microbiological } \\
\text { and cytological examinations, polymerase chain } \\
\text { reaction assay) positive for SARS-CoV-2 }\end{array}$ & $\begin{array}{l}\text { During hospitalization: antimicrobial empiric } \\
\text { treatment with orally administered azithromycin } \\
(500 \mathrm{mg} \mathrm{qd}) \text { and parenterally administered } \\
\text { ceftriaxone ( } 2 \mathrm{~g} \text { /day) for } 6 \text { days, starting } 3 \text { days } \\
\text { before ribavirin aerosol treatment was initiated } \\
\text { No supplemental oxygen required }\end{array}$ \\
\hline Patient 2 & $\begin{array}{l}\text { Before hospital admission: nasopharyngeal swab } \\
\text { positive for SARS-CoV-2 }\end{array}$ & $\begin{array}{l}\text { Before admission: hydroxychloroquine, azithromycin } \\
\text { During hospitalization (before exclusion of secondary } \\
\text { infections): levofloxacin } 750 \mathrm{mg} \text { qd, parenterally } \\
\text { administered dexamethasone } 6 \mathrm{mg} / \mathrm{day} \text {, and orally } \\
\text { administered lopinavir/ritonavir ( } 200 \mathrm{mg} / 50 \mathrm{mg} \\
\text { tablet bid) for } 7 \text { days } \\
\text { Levofloxacin and lopinavir/ritonavir discontinued, and } \\
\text { dexamethasone switched to orally administered } \\
\text { prednisone } 25 \mathrm{mg} \text { qd, which was reduced to } 12.5 \mathrm{mg} \\
\text { qd for } 2 \text { days and then discontinued } \\
\text { Supplemental low flow oxygen on days } 2 \text { and } 3 \text { of } \\
\text { ribavirin therapy }\end{array}$ \\
\hline Patient 3 & $\begin{array}{l}\text { Before hospital admission: nasopharyngeal swab } \\
\text { positive for SARS-CoV-2 } \\
\text { At admission: serology test positive for SARS-CoV-2 } \\
\text { antibodies }\end{array}$ & $\begin{array}{l}\text { Before admission: orally administered azithromycin } \\
500 \mathrm{mg} / \text { day and orally administered prednisone } \\
25 \mathrm{mg} / \text { day for } 10 \text { days } \\
\text { During hospitalization: no other antiviral or } \\
\text { immunomodulating treatments; no supplemental } \\
\text { oxygen required }\end{array}$ \\
\hline Patient 4 & $\begin{array}{l}\text { Before hospital admission: nasopharyngeal swab } \\
\text { positive for SARS-CoV-2 } \\
\text { At admission: repeat nasopharyngeal swab positive for } \\
\text { SARS-CoV-2 }\end{array}$ & $\begin{array}{l}\text { During hospitalization: no other antiviral or } \\
\text { immunomodulating treatments; no supplemental } \\
\text { oxygen required }\end{array}$ \\
\hline
\end{tabular}

scan showed moderate clearing of the bilateral parenchymal thickening previously described (with parenchymal involvement of approximately $10 \%$ ), some bands of atelectasis, and stable small mediastinal lymph nodes (Fig. 3).
The patient was discharged from the hospital later that day. At the end of quarantine, two sequential nasopharyngeal swabs for SARS-CoV2 yielded negative results. 
Table 2 continued

\begin{tabular}{|c|c|c|}
\hline Case & Diagnosis & Treatments in addition to ribavirin aerosol ${ }^{a}$ \\
\hline Patient 5 & $\begin{array}{l}\text { At admission: nasopharyngeal swab negative for SARS- } \\
\text { CoV-2 } \\
\text { During hospitalization: nasopharyngeal swab with } \\
\text { weak positive result followed by nasopharyngeal swab } \\
\text { with a confirmatory positive result and serology test } \\
\text { positive for SARS-CoV-2 antibodies }\end{array}$ & $\begin{array}{l}\text { During hospitalization (before diagnosis was } \\
\text { confirmed): empiric treatment with antibiotics } \\
\text { (piperacillin/tazobactam) for } 7 \text { days and low-flow } \\
\text { supplemental oxygen } \\
\text { During ribavirin therapy: no other antiviral or } \\
\text { immunomodulating treatments; no supplemental } \\
\text { oxygen required }\end{array}$ \\
\hline
\end{tabular}

$\overline{{ }^{a} \text { All patients received low-molecular-weight heparin throughout hospitalization except patient } 5 \text {, who received prophylaxis }}$ with enoxaparin and an antiplatelet agent to reduce thromboembolic risk

\section{Patient 1}

Pretreatment

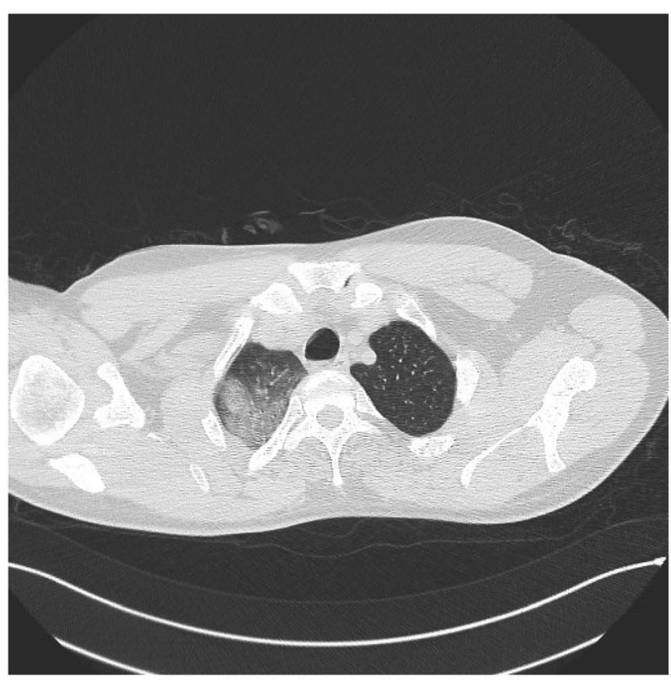

Fig. 1 Chest computed tomography scans without contrast for patient 1 at pretreatment, showing pseudonodular areas of parenchymal thickening in the upper right lobe with associated ground glass areas and some reactive

\section{Patient 4}

A chest CT scan without contrast that was performed on the day of hospital admission (October 29, 2020) showed parenchymal thickening and multiple associated ground glass areas with crazy paving aspects, predominantly at the basal pyramid of both lower lobes

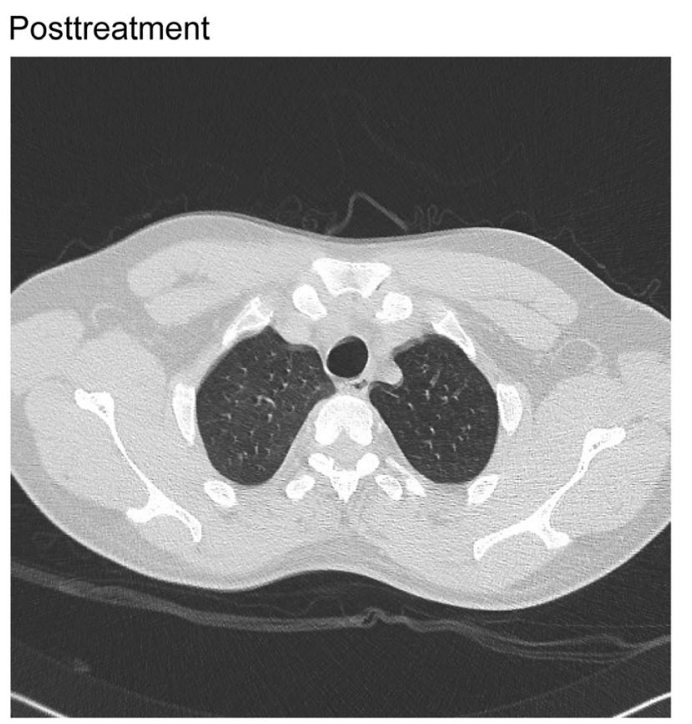

mediastinal lymph nodes, and posttreatment after 6 days of therapy with ribavirin solution for inhalation, showing resolution of the pseudonodular areas and minimal residual subpleural areas

(involving approximately 10\% of the lung parenchyma) and small mediastinal lymph nodes (Fig. 4; Table 2). The patient was enrolled in the compassionate use study and treated with nebulized ribavirin from October 30 through November 3. The patient requested hospital discharge on November 3 for family reasons and, therefore, received 10 of the planned 12 


\section{Patient 2}

\section{Pretreatment}

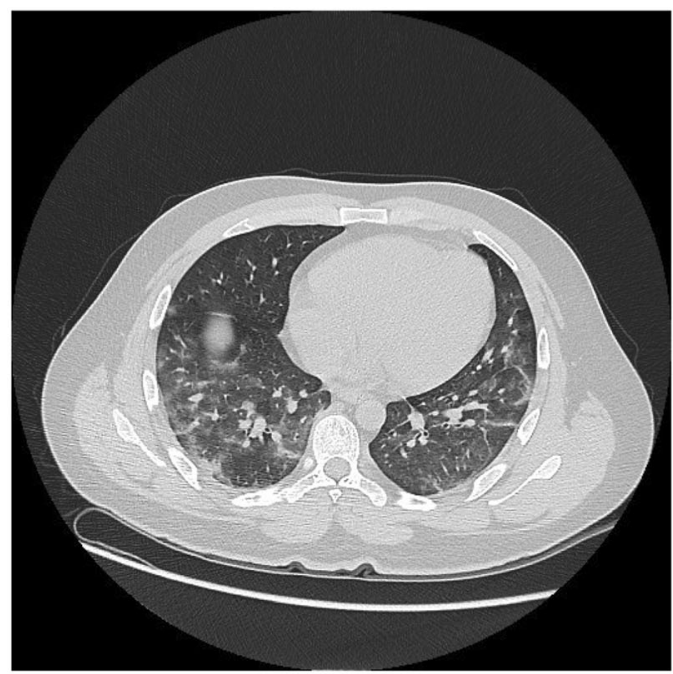

Fig. 2 Chest computed tomography scans without contrast for patient 2 at pretreatment, showing multiple areas of parenchymal consolidation affecting the lower lobes of both lungs with associated ground glass areas, and

\section{Patient 3}

\section{Pretreatment}

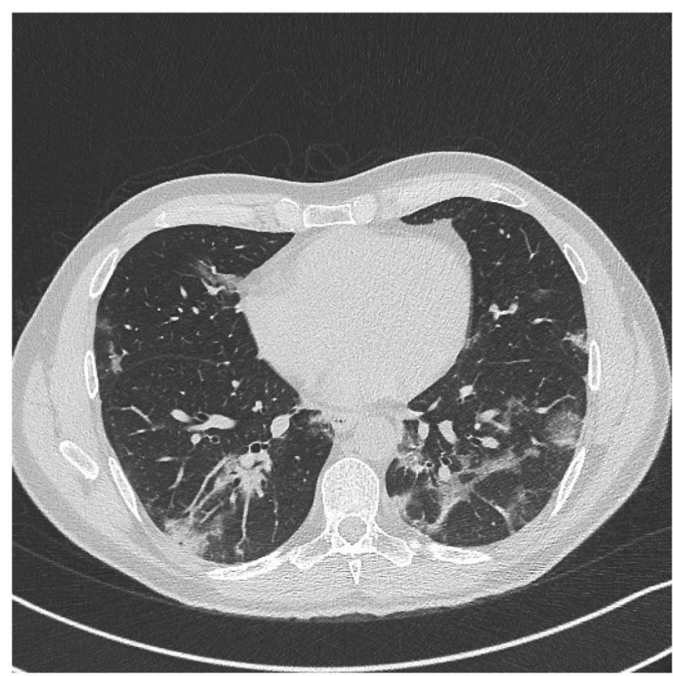

Fig. 3 Chest computed tomography scans without contrast for patient 3 at pretreatment, showing bilateral parenchymal thickening and multiple associated ground glass areas with crazy paving and some reactive mediastinal

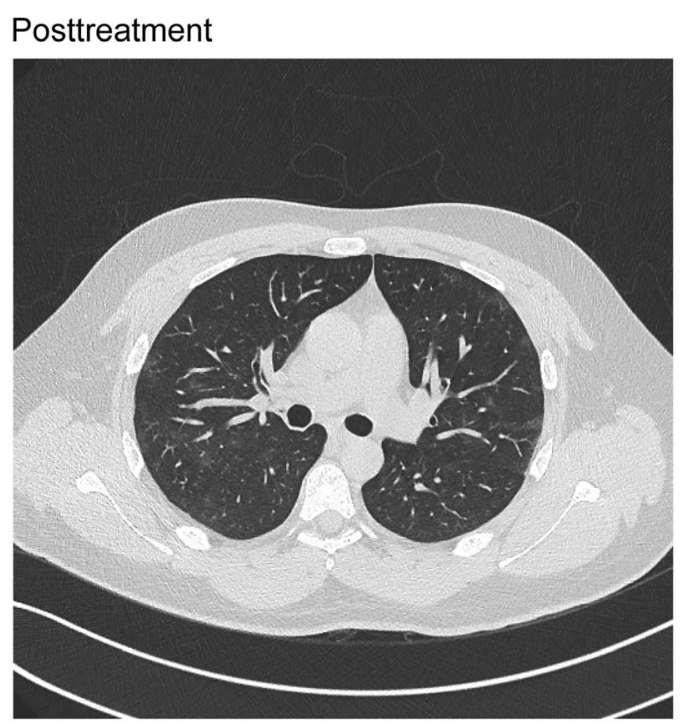

posttreatment after 6 days of therapy with ribavirin solution for inhalation, showing almost complete resolution of the parenchymal consolidation and ground glass areas

\section{Posttreatment}

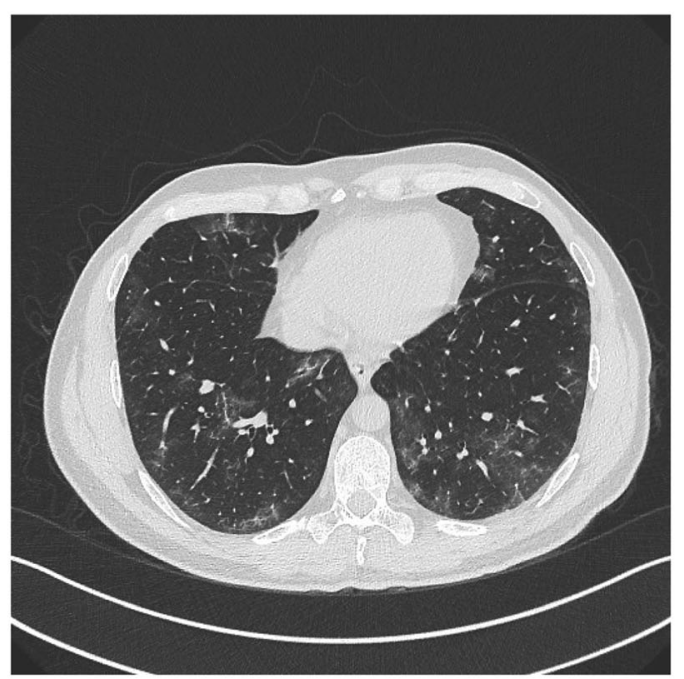

lymph nodes, and posttreatment after 6 days of therapy with ribavirin solution for inhalation, showing moderate clearing of the bilateral parenchymal thickening and stable small mediastinal lymph nodes 
doses. The patient was apyretic after the first 2 days of ribavirin therapy, and the cough subsided.

A chest CT scan performed on the fifth day of ribavirin aerosol therapy (November 3) showed a stationary pulmonary picture with parenchymal involvement of less than 10\% (Fig. 4). The patient was discharged from the hospital on November 3; at discharge, a nasopharyngeal swab tested positive for SARS-CoV-2. A followup nasopharyngeal swab for SARS-CoV-2 that was performed on November 17 (end of quarantine) yielded negative results.

\section{Patient 5}

The patient was admitted to the hospital on December 26, 2020. Empiric treatment with antibiotics (Table 2 ) provided limited improvement. On January 21, a nasopharyngeal swab tested positive for SARS-CoV-2, and a chest CT scan without contrast showed focal ground

\section{Patient 4}

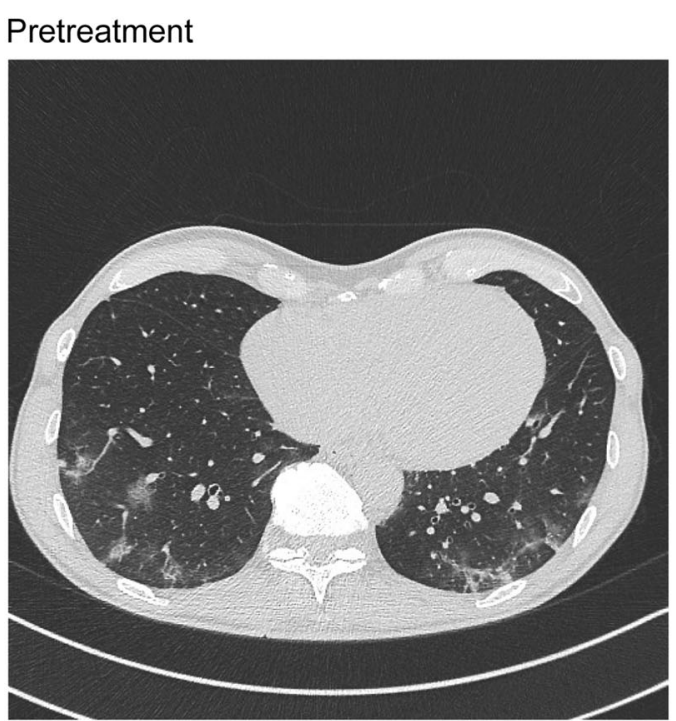

Fig. 4 Chest computed tomography scans without contrast for patient 4 at pretreatment, showing parenchymal thickening and multiple associated ground glass areas with crazy paving aspects, predominantly at the basal pyramid of glass areas, mainly located in the upper lobes bilaterally, with the largest in the medial area of the middle lobe (Fig. 5). There were no signs of interstitial thickening and no evidence of lymphadenomegaly in the mediastinal area. These findings were considered consistent with COVID-19 interstitial pneumonia and grossly affected $5-10 \%$ of the lung parenchyma. A serology test for SARS-CoV-2 antibodies was positive. The patient was enrolled in the compassionate use study and treated with nebulized ribavirin from January 21 through January 27. On day 3 of ribavirin aerosol therapy, a nasopharyngeal swab again tested positive for SARS-CoV-2.

A CT scan performed on February 1 showed complete resolution of the ground glass thickening in the parenchymal area, with only a few areoles persistently and slightly thickened (Fig. 5). On February 3 (1 week after the last dose of ribavirin aerosol), viral clearance was verified with a negative nasopharyngeal swab. The patient was discharged from the hospital on

\section{Posttreatment}

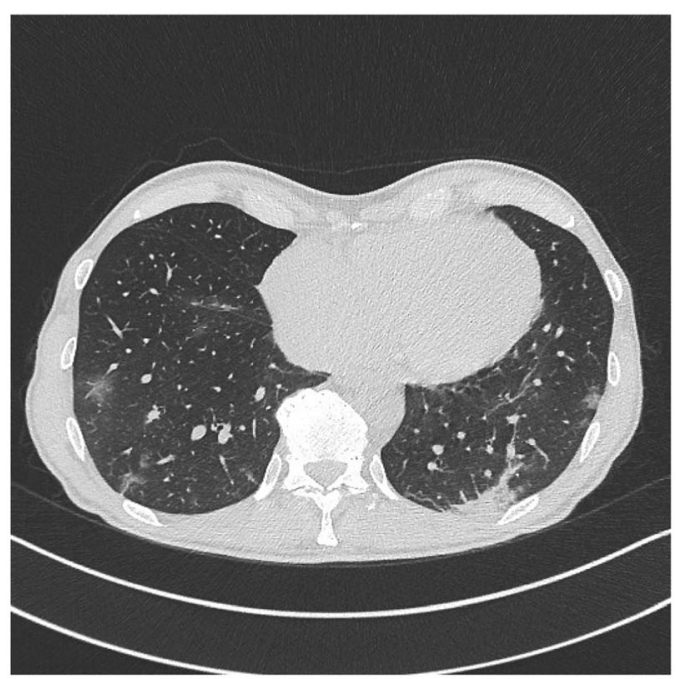

both lower lobes, and posttreatment after 5 days of therapy with ribavirin solution for inhalation, showing a stationary pulmonary picture 


\section{Patient 5}

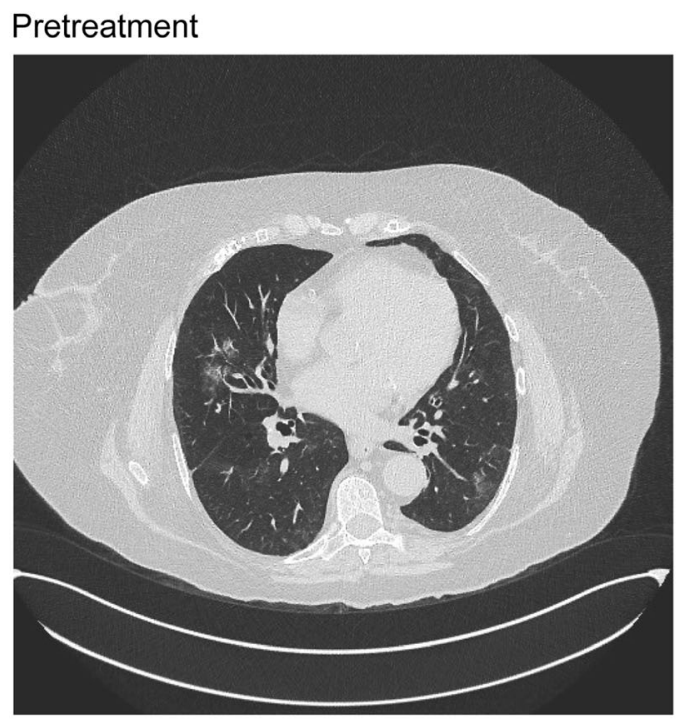

Fig. 5 Chest computed tomography scans without contrast for patient 5 at pretreatment, showing focal ground glass areas, mainly located in the upper lobes bilaterally, with the largest in the medial area of the middle lobe, and

February 4 in good clinical condition. At the end of quarantine, two sequential nasopharyngeal swabs for SARS-CoV-2 yielded negative results.

\section{Safety and Tolerability}

In all cases, treatment with ribavirin aerosol was well tolerated, and no adverse effects on the skin or eyes were observed. No bronchospasm was reported during treatment, and no changes in heart rhythm were recorded. All patients received low-molecular-weight heparin throughout hospitalization except patient 5 , who received prophylaxis with enoxaparin and an antiplatelet agent to reduce thromboembolic risk.

\section{DISCUSSION}

Identification of pharmacologic treatments that induce viral containment and clearance of SARS-CoV-2 is important for addressing the global COVID-19 pandemic [6]. The details reported here illustrate the potential benefit of

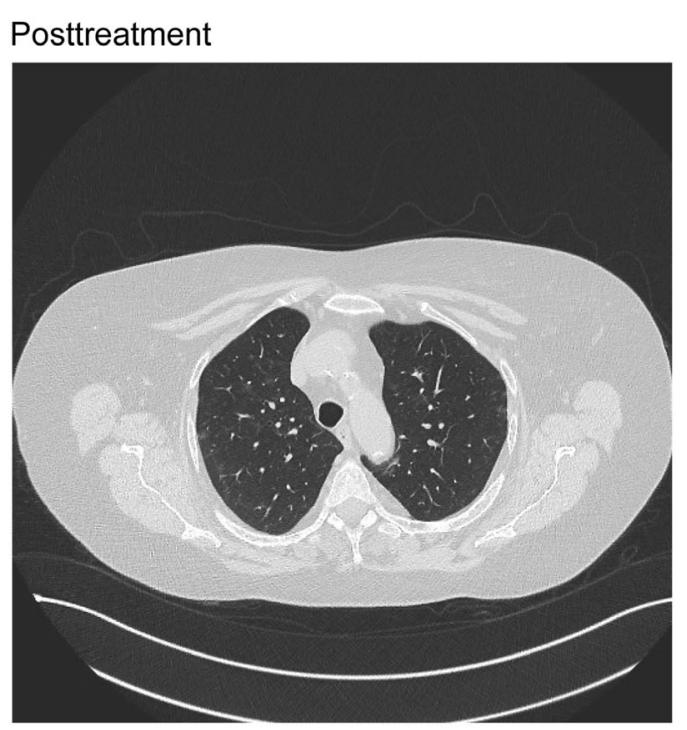

posttreatment, showing almost complete resolution of the ground glass thickening in the parenchymal area, with only a few areoles persistently and slightly thickened

administration of ribavirin aerosol in hospitalized patients with COVID-19. Three of these five patients with confirmed SARS-CoV-2 infection were initially treated empirically with antibiotics; one of them (patient 2) also received corticosteroids and other antiviral medications. Two patients received no antiviral or immunomodulating treatments other than ribavirin. Ribavirin aerosol treatments (12 doses administered over 6 days) were provided as part of a compassionate use program. Rapid improvement in respiratory symptoms was observed after initiation of ribavirin aerosol therapy and was followed by effective viral clearance. Pretreatment CT scans showed pseudonodular areas of parenchymal thickening in the upper right lobe with associated ground glass opacities (patient 1), multiple areas of parenchymal consolidation in both lower lobes with associated ground glass opacities (patient 2), bilateral parenchymal thickening and multiple associated ground glass areas (patient 3), and focal ground glass areas in the upper lobes bilaterally (patient 5), which were almost completely resolved (patients 1, 2, and $5)$ or moderately cleared (patient 3 ) on post- 
treatment imaging. For patient 4, CT scans showed a stable pulmonary picture. All patients recovered fully, and nasopharyngeal swabs obtained after hospital discharge were negative for SARS-CoV-2.

An experimental dosing regimen of aerosolized ribavirin was developed for the treatment of SARS-CoV-2 infection in order to deliver medication in a shorter treatment period. The FDA-recommended dosing for patients with respiratory syncytial virus is a solution of $20 \mathrm{mg} / \mathrm{mL}$ with continuous aerosol administration for $12-18 \mathrm{~h}$ per day for 3-7 days [11]. Research using animal models demonstrated that the use of a higher concentration ribavirin solution $(60 \mathrm{mg} / \mathrm{mL})$ could significantly reduce treatment time [16, 17]. Ribavirin $100 \mathrm{mg} / \mathrm{mL}$ administered using a more efficient nebulizer was effective in reducing mortality in a lethal influenza A virus mouse model [18]. Administration of ribavirin aerosol $100 \mathrm{mg} / \mathrm{mL}$ for $30 \mathrm{~min}$ is estimated to deliver $1760 \mu \mathrm{g} / \mathrm{mL}$ to the alveolar lining fluid, which is approximately 64 times the half maximal response $\left(\mathrm{EC}_{50}\right)$ of $26.7 \mu \mathrm{g} / \mathrm{mL}$ observed against a clinical isolate of SARS-CoV-2 in vitro (data on file). Administration of ribavirin aerosol as recommended in the treatment of respiratory syncytial virus $(20 \mathrm{mg} /$ $\mathrm{mL}$ over $12 \mathrm{~h}$ ) [11] results in an estimated dose of $10.9 \mathrm{mg} / \mathrm{kg}$, whereas administration in the compassionate use study (ribavirin aerosol $100 \mathrm{mg} / \mathrm{mL}$ for $30 \mathrm{~min}$ ) results in an estimated dose of $5.1 \mathrm{mg} / \mathrm{kg}$, which represents approximately half the systemic exposure (data on file).

In vitro and clinical data suggest that ribavirin may be an effective therapeutic in the medical management strategy of patients with COVID-19. In vitro research has demonstrated antiviral efficacy for lopinavir and ribavirin against SARS-associated coronavirus, and a clinical study showed that patients with probable SARS-CoV treated with a combination of lopinavir/ritonavir, ribavirin (oral or intravenous), and corticosteroids $(n=41)$ had a significantly lower rate of adverse clinical outcomes (i.e., acute respiratory distress syndrome or patient mortality) than a historical control group treated with ribavirin and corticosteroids $(n=111 ; \quad P<0.001) \quad$ [19]. Other in vitro studies have shown that MERS-CoV is sensitive to a combination of ribavirin and interferon- $\alpha 2 b$ [20]. A publication regarding a 38-year-old man diagnosed with COVID-19 reported the successful use of intravenously administered ribavirin as one component of medical therapy that also included antibiotics, antitussives, bronchodilators, and interferon$\alpha 1 b$ [21]. A 2020 open-label, randomized, phase 2 trial in hospitalized patients with COVID-19 evaluated 14-day combination therapy $(n=86)$ with orally administered lopinavir/ ritonavir, orally administered ribavirin, and subcutaneously administered interferon- $\beta 1 \mathrm{~b}$ (in the subset of 52 patients admitted less than 7 days from symptom onset) compared with a control group that received only orally administered lopinavir/ritonavir $(n=41)$ [22]. That study found that the combination treatment was significantly better for alleviating symptoms, reducing viral load, and shortening the duration of hospitalization.

Although the mechanisms of action have not been fully elucidated, ribavirin has broad antiviral effects that appear to target both viral and host responses [23]. Proposed mechanisms for the antiviral efficacy of ribavirin, which may be concentration dependent, include the inhibition of inosine monophosphate dehydrogenase leading to changes in the balance of intracellular nucleotide concentrations, inhibition of mRNA capping, alterations in host cell gene expression, inhibition of viral RdRp, and enhancement of viral mutagenesis [23]. In the treatment of SARS-CoV-2 infection, ribavirin could reduce lung involvement indirectly through reduction of viral replication and local shedding. This could reduce viral exposure to alveolar dendritic cells and Tlymphocytes, thereby limiting the inflammatory cascade mediated by cytokines and chemokines, which is the main mechanism of alveolar damage and alteration in respiratory exchange.

None of the five patients included in this case series required admission to an intensive care unit, and the effectiveness of ribavirin aerosol for severe presentations of COVID-19 is unclear. However, the results of a randomized, double-blind, placebo-controlled study support the feasibility and efficacy of using ribavirin aerosol treatment in infants requiring 
mechanical ventilation for respiratory failure caused by respiratory syncytial virus infection [24].

Potential advantages with ribavirin aerosol treatment for patients with COVID-19 versus oral or intravenous formulations include direct targeting of medication to the site of infection and a lower risk for adverse events that are associated with systemic administration. However, there are concerns about using an aerosol treatment in patients infected with SARS-CoV-2 because of increased risk of healthcare providers being exposed to the virus. It is known that the drug can disperse into the bedside area during treatment with ribavirin aerosol [11], and the extent to which treatment may also impact virus dispersal is unclear. In addition to the standard precautions taken when treating patients with COVID-19, it is recommended that healthcare providers wear a facemask (as well as eye protection, gloves, and a gown), close the door to the patient room, and remain at a safe distance (possibly outside the door) during nebulizer treatments [25]. In the current report, healthcare providers wore FFP3 masks and remained outside the patient room during ribavirin aerosol treatment. The short duration of therapy (30 min bid) means that this restriction in patient contact would not be expected to compromise patient care.

\section{CONCLUSION}

Ribavirin is an inosine monophosphate dehydrogenase inhibitor with demonstrated activity against coronaviruses, including SARS-CoV-2, in preclinical research. The positive preliminary findings obtained and reported here, both in terms of efficacy and safety, support continuation of the compassionate use study and execution of further clinical studies (e.g., ClinicalTrials.gov identifiers NCT04356677 and NCT04551768) to evaluate whether ribavirin for inhalation (ribavirin aerosol) may be a useful option in the treatment of patients with COVID-19.

\section{ACKNOWLEDGEMENTS}

The authors thank the patients for their participation in the study.

Funding. Study medication and equipment for drug administration were provided by Bausch Health, Milan, Italy. Funding for publication fees and technical editorial and medical writing assistance was provided by Bausch Health, Bridgewater, NJ, USA.

Medical Writing and Editorial Assistance. Technical editorial and medical writing assistance was provided, under direction of the authors, by Mary Beth Moncrief, PhD, and Nancy Holland, PhD, Synchrony Medical Communications, LLC, West Chester, PA.

Authorship. All named authors meet the International Committee of Medical Journal Editors (ICMJE) criteria for authorship for this article, take responsibility for the integrity of the work as a whole, and have given their approval for this version to be published.

Authorship Contributions. Emanuela Messina: data acquisition, drafting the manuscript, critical review and revision. Anna Danise: data acquisition, critical review and revision. Giulio Ferrari: data acquisition, critical review and revision. Andrea Andolina: data acquisition, critical review and revision. Matteo Chiurlo: data acquisition, critical review and revision. Marie Razanakolona: data acquisition, critical review and revision. Maxime Barakat: concept and design, critical review and revision. Robert J. Israel: concept and design, critical review and revision. Antonella Castagna: concept and design, acquisition of data, drafting the manuscript, critical review and revision.

Disclosures. Emanuela Messina reports nothing to disclose. Anna Danise reports nothing to disclose. Giulio Ferrari reports nothing to disclose. Andrea Andolina reports nothing to disclose. Matteo Chiurlo reports nothing to disclose. Marie Razanakolona reports nothing to disclose. Maxime Barakat and Robert J. Israel are employees of Bausch Health Companies Inc. 
Antonella Castagna reports receiving consulting fees from Gilead, Janssen, MSD, Theratechnologies, and ViiV Healthcare.

Compliance with Ethics Guidelines. Approval for the compassionate use program was obtained from an ethics committee (IRCCS Lazzaro Spallanzani, Rome, Italy; and San Raffaele Scientific Institute, Milan, Italy) before treatment was initiated. Study conduct was in accordance with the Helsinki Declaration of 1964 and its later amendments. All patients provided written informed consent for participation in the compassionate use program and for their information and images to be published in this article.

Data Availability. Data sharing is not applicable to this article as no datasets were generated or analyzed for this case series.

Open Access. This article is licensed under a Creative Commons Attribution-NonCommercial 4.0 International License, which permits any non-commercial use, sharing, adaptation, distribution and reproduction in any medium or format, as long as you give appropriate credit to the original author(s) and the source, provide a link to the Creative Commons licence, and indicate if changes were made. The images or other third party material in this article are included in the article's Creative Commons licence, unless indicated otherwise in a credit line to the material. If material is not included in the article's Creative Commons licence and your intended use is not permitted by statutory regulation or exceeds the permitted use, you will need to obtain permission directly from the copyright holder. To view a copy of this licence, visit http://creativecommons.org/licenses/by$\mathrm{nc} / 4.0 /$.

\section{REFERENCES}

1. Petrosillo N, Viceconte G, Ergonul O, Ippolito G, Petersen E. COVID-19, SARS and MERS: are they closely related? Clin Microbiol Infect. 2020;26: 729-34.
2. Zumla A, Hui DS, Azhar EI, Memish ZA, Maeurer M. Reducing mortality from 2019-nCoV: host-directed therapies should be an option. Lancet. 2020;395: e35-6.

3. Tay MZ, Poh CM, Renia L, MacAry PA, Ng LFP. The trinity of COVID-19: immunity, inflammation and intervention. Nat Rev Immunol. 2020;20:363-74.

4. Huang C, Wang Y, Li X, et al. Clinical features of patients infected with 2019 novel coronavirus in Wuhan, China. Lancet. 2020;395:497-506.

5. Xu Z, Shi L, Wang Y, et al. Pathological findings of COVID-19 associated with acute respiratory distress syndrome. Lancet Respir Med. 2020;8:420-2.

6. Artese A, Svicher V, Costa G, et al. Current status of antivirals and druggable targets of SARS CoV-2 and other human pathogenic coronaviruses. Drug Resist Updat. 2020;53:10072.

7. Hedstrom L. IMP dehydrogenase: structure, mechanism, and inhibition. Chem Rev. 2009;109: 2903-28.

8. Elfiky AA. Anti-HCV, nucleotide inhibitors, repurposing against COVID-19. Life Sci. 2020;248: 117477.

9. Copegus (ribavirin, USP) Tablets [package insert]. Nutley, NJ: Roche Laboratories Inc.; 2005

10. Ribavirin $200 \mathrm{mg}$ film-coated tablets [package insert]. South Ruislip, UK: Aurobindo PharmaMilpharm Ltd.; 2020.

11. Virazole (ribavirin for inhalation solution, USP) prescribing information [package insert]. Bridgewater, NJ: Bausch Health US, LLC; 2019.

12. Virazole (ribavirin for inhalation) Solution, USP [product monograph]. Leval, Quebec, Canada: Bausch Health Canada Inc; 2020.

13. Knight V, Wilson SZ, Quarles JM, et al. Ribavirin small-particle aerosol treatment of influenza. Lancet. $1981 ; 318: 945-9$.

14. Wilson SZ, Gilbert BE, Quarles JM, et al. Treatment of influenza A (H1N1) virus infection with ribavirin aerosol. Antimicrob Agents Chemother. 1984;26: 200-3.

15. Gilbert BE, Wilson SZ, Knight V, et al. Ribavirin small-particle aerosol treatment of infections caused by influenza virus strains A/Victoria/7/83 (H1N1) and B/Texas/1/84. Antimicrob Agents Chemother. 1985;27:309-13.

16. Gilbert BE, Wyde PR, Ambrose MW, Wilson SZ, Knight V. Further studies with short duration 
ribavirin aerosol for the treatment of influenza virus infection in mice and respiratory syncytial virus infection in cotton rats. Antiviral Res. 1992;17: 33-42.

17. Wyde PR, Wilson SZ, Petrella R, Gilbert BE. Efficacy of high dose-short duration ribavirin aerosol in the treatment of respiratory syncytial virus infected cotton rats and influenza B virus infected mice. Antiviral Res. 1987;7:211-20.

18. Gilbert BE, McLeay MT. MegaRibavirin aerosol for the treatment of influenza A virus infections in mice. Antiviral Res. 2008;78:223-9.

19. Chu CM, Cheng VC, Hung IF, et al. Role of lopinavir/ritonavir in the treatment of SARS: initial virological and clinical findings. Thorax. 2004;59: 252-6.

20. Falzarano D, de Wit E, Martellaro C, Callison J, Munster VJ, Feldmann H. Inhibition of novel beta coronavirus replication by a combination of interferon- $\alpha 2 b$ and ribavirin. Sci Rep. 2013;3:1686.

21. Zhou C, Gao C, Xie Y, Xu M. COVID-19 with spontaneous pneumomediastinum. Lancet Infect Dis. 2020;20:510.
22. Hung IF-N, Lung K-C, Tso EY-K, et al. Triple combination of interferon beta-1b, lopinavir-ritonavir, and ribavirin in the treatment of patients admitted to hospital with COVID-19: an open-label, randomised, phase 2 trial. Lancet. 2020;395:1695-704.

23. Nyström K, Waldenström J, Tang KW, Lagging M. Ribavirin: pharmacology, multiple modes of action and possible future perspectives. Future Virol. 2019; 14:153-60.

24. Smith DW, Frankel LR, Mathers LH, Tang ATS, Ariagno RL, Prober CG. A controlled trial of aerosolized ribavirin in infants receiving mechanical ventilation for severe respiratory syncytial virus infection. N Engl J Med. 1991;325:24-9.

25. Minnesota Department of Health. Aerosol-generating procedures and patients with suspected or confirmed COVID-19. St. Paul: Minnesota Department of Health; 2020. 